International Journal of Engineering \& Technology, $7(2.34)(2018)$ 16-21
International Journal of Engineering \& Technology
SPC
Website: www.sciencepubco.com/index.php/IJET
Research paper

\title{
An Innovative Web 2.0-Based Collaborative Learning Framework: Activities for The Initial Development of Social Negotiation Competencies
}

\author{
Farib Ataie, Asadullah Shah,sharifa Bahar, Najma Imtiaz Ali \\ Kulliyyah of Information \&Communication Technology \\ International Islamic University Malaysia (IIUM) \\ Gombak, 53100 Kuala Lumpur \\ *Corresponding author E-mail fariba.ataie38@gmail.com,
}

\begin{abstract}
This research aims to present a Facebook-based collaborative learning (CL) framework that supports initial development of social negotiation and debate competencies. This framework has implications for the International Debate Education Association (IDEA, 2018) that aims to promote the opportunity to debate, breaking down barriers of location, race and class while extending the boundaries of onlinelearning. The guidelines for CL and social negotiation in this study are based on social constructivist theory with the ethical system that value safe and structured environment for debate and negotiation. The integration of Facebook as an information and communication technology (IICT) provides conditions of CL and social negotiation, multiple modes and methods of learning and multiple perspectives, to achieve learning goals. This practical framework under the guidelines of design science research methodology (DSRM) motivates learners to actively engage in the CL and social negotiation processes with empathy, self- control, endurance and reasoning to develop critical thinking and awareness. This study will contribute to the World Universities Debating Championship (WUDC) that aims to complement communication skills of students with a culture of research and critical thinking. Experts reviewed and confirmed the validity of the framework. Three successive iterations working with Facebook members and experts in informal learning were conducted to demonstrate and validate how learners started developing social negotiation and debate competencies.
\end{abstract}

Keywords: Web 2.0-based collaborative learning and social negotiation, International Debate Education Association, social constructivist theory, DSRM

\section{Introduction}

The main goal of this research is developing an innovative Web 2.0-base CL framework that supports learning together and initial development of social negotiation and competencies [1]. CL and social negotiation is not only a method of instruction, but it prepares learners for challenges in life and gives priority to the group. Social negotiation motivates them to talk with each other, helps learners to express and challenge others' ideas, persuades them to accept mistakes and encourages them to support one another [2]. In the history of Islamic education, (the Halaqah: which is a type of Study Circle), played an important role in developing the culture of CL and social negotiation in the Muslim communities [3]. Asserts that Web 2.0-based CL with Islamic ethical system allow students to learn how to negotiate and collaborate with empathy; control their emotions and feelings and communicate morally[4]. Students must learn to actively engage with real world problems and keep their mind as well as their hands open for solving the problems of unknown and uncertain nature [4]. They must learn to respect others' beliefs and collaborate with them. It is not a competition and a struggle to win. Students must learn collaboration and negotiation, not the reception [5] Driscol (2005) concludes that the social constructivism theory with the CL method of instruction in an e-learning platform could motivate students achieve goals of instruction, awareness, self-control and empathy[6]. Also, its potential for negotiation could help them to be open-minded and increase their endurance and critical thinking. Islam encourages collaboration and social negotiation with an emphasis on endurance, self-control and to get information and follow the best one (Ali'Imran 3:200; Al-Zumar, 39:18). This is in line with the IDEA (2018) goals that emphasises on reason, CL and the careful weighing of evidence. Therefore, this study's developed artifact could contribute WUDC that aims to complement communication skills of students with a culture of research and critical thinking.

\section{Web 2.0-Based CL Framework Promoting Debate and Social Negotiation}

The Web2.0-based CL Framework in this study has 3 parts, theoretical model, and activities for the initial development of debate and social negotiation competencies and the practical experiencebased framework under the guidelines of Design Science Research Methodology (DSRM) 


\subsection{Theoretical Model}

The CL and social negotiation model in this study is adapted from [6] in social constructivist theory that includes three parts: learning methods, conditions and goals. Face book's basic functions such as walls, Chat, photos, videos, Pictures, groups, pages, com- ment area and home page are considered for CL that could support debate and social negotiation conditions [7][8]. The multiple modes of learning and multiple perspectives, motivate students for more engagement in the CL process to achieve social negotiation goals: critical thinking and awareness details

All title and author details must be in single-column format and must

be

centred

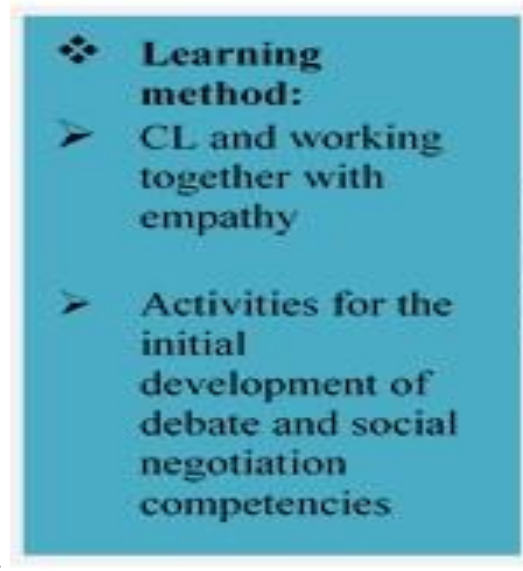

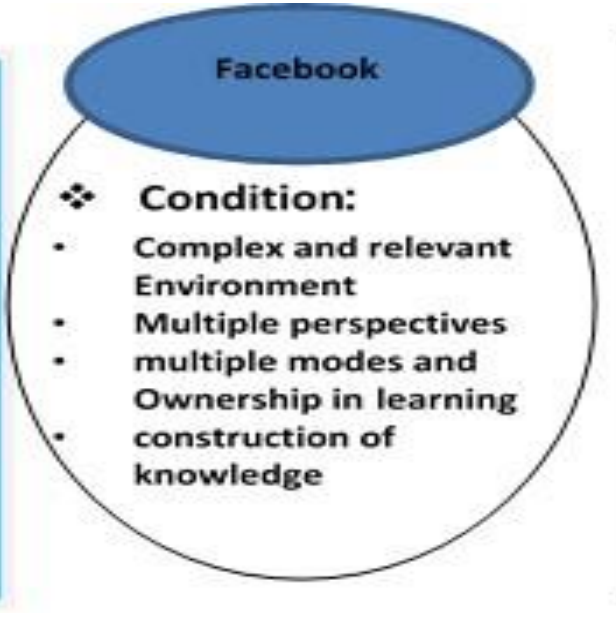

Fig 1: Theoretical model

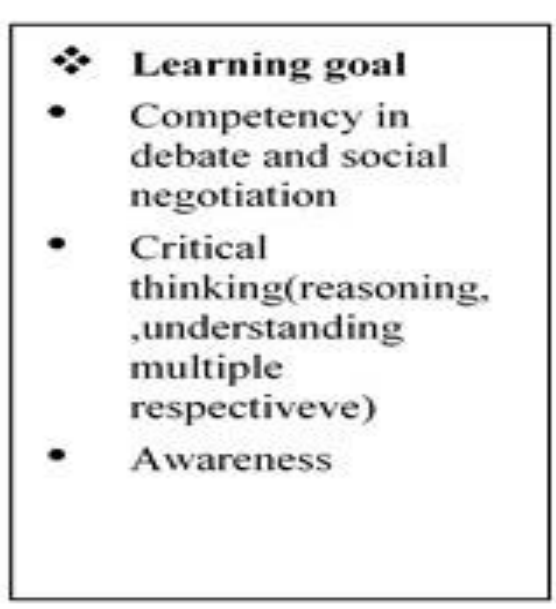

\subsection{Activities for the Initial Development of Debate and So-} cial Negotiation Competencies Action Plan

This study categorised all goals, then determined constructs for them through a literature review and a review of theories. Furthermore, this study designed practical activities based on researcher experience and literature review. This study's developed action plan could be used for training in class and motivate students to engage and practice CL (empathy, teamwork and social negotiation) to achieve goals: awareness and critical thinking (reasoning, understanding multiple perspectives) [9]

The information, communication and collaboration tools of Facebook are considered for pedagogical strategy in this study. Facebook chat and comment areas help facilitate social negotiation. The discussion and social negotiation help prompt prior knowledge, which is the first criterion of constructivist learning. Similarly, the comment areas as discussion boards are used for reflection which is the main criterion of constructivist learning [10]. This study considered features of Facebook that could provide a valid, practical and effective virtual space in which learners could learn together toward common goals. They can negotiate about different topics, give their opinions and share their videos, pictures, Information and knowledge in Facebook page and groups. Such virtual communities are not only solely limited to sharing information, but also, a social sense of belonging to a group arises in them [11]. The feeling of empathy and belonging to a group supports collaborative learning. Table 1

\subsection{The Ethical System}

The findings of literature, [5] and [12] emphasise on using the ethical system and cyber ethics for web 2.0 based CL and social negotiation. Therefore, this study considering all findings and suggestions of literatures developed an Islamic ethical system for Web 2.0 based CL and social negotiation that could provide safe and evidence-based platform that is the main goal of IDEA (Figure 2). All findings from literatures confirmed that practicing CL and social negotiation with the Islamic ethical system to clarify the truth could increase awareness and develop critical thinking of participants not only in the virtual world, but also in their real life.
Table Error! No text of specified style in document: Features of Facebook(FB), design strategies and Learning goals

\begin{tabular}{|c|c|c|}
\hline $\begin{array}{c}\text { Facebook } \\
\text { features }\end{array}$ & $\begin{array}{l}\text { Characteristic and design strat- } \\
\text { egies }\end{array}$ & Design goals \\
\hline FB wall & $\begin{array}{l}\text { People and students could share } \\
\text { and get information }\end{array}$ & awareness and \\
\hline \multirow[t]{3}{*}{$\begin{array}{l}\text { Comment } \\
\text { areas and } \\
\text { chat of } \\
\text { FB }\end{array}$} & $\begin{array}{l}\text { Exchange diverse be- } \\
\text { liefs,experience and practice } \\
\text { negotiation develop the ability } \\
\text { to think and act us- } \\
\text { ing knowledge }\end{array}$ & wisdom \\
\hline & $\begin{array}{l}\text { Supports synchronous and } \\
\text { asynchronous communication } \\
\text { and interaction } \\
\text { CL with empathy,practicing } \\
\text { self-control and endurance } \\
\text { Research and team work }\end{array}$ & $\begin{array}{c}\text { CL,Debate and Social } \\
\text { negotiation competencies }\end{array}$ \\
\hline & $\begin{array}{l}\text { People, instructors and students, } \\
\text { discuss about different issues, } \\
\text { especially which engaged with } \\
\text { the debate series in the universi- } \\
\text { ty debating championship } \\
\text { Social negotiation and presents } \\
\text { own ideas and exchange diverse } \\
\text { beliefs } \\
\text { Answer questions and reason } \\
\text { with reliable evidence }\end{array}$ & \multirow[t]{2}{*}{$\begin{array}{l}\text { To Develop critical think- } \\
\text { ing } \\
\text { (Reasoning,understanding } \\
\text { multiple perspectives) }\end{array}$} \\
\hline $\begin{array}{l}\text { FB video } \\
\text { and pic- } \\
\text { tures }\end{array}$ & $\begin{array}{l}\text { Learners could construct their } \\
\text { own knowledge by creating } \\
\text { videos and taking pictures. This } \\
\text { leads to connection between } \\
\text { visual clues, the memory pro- } \\
\text { cess, and the recall of new } \\
\text { knowledge. }\end{array}$ & \\
\hline
\end{tabular}




\section{1-Negotiation for clarifying truth and learning \\ Surah Al-Kahf [18:22] "...So do not argue about them except with an obvious \\ argronent..."}

2-Negotiating in clear $w$ ay that it is not in doubt $w$ ith reasons and authoritative

Resources

Surah al-Najm [53:28] "And they have thereof no knowledge. They follow not except assumption, and indeed, assumption avails not against the truth at all."

\section{3-Not rid icule, not in sult}

Surat Al-Hujwat [verse 11] "O you who have believed, let not a people ridicule [another] people; perhaps they may be better than them..."

4-Avoid negativ e assump tion,

Surat Al-Hujwat [verse 12] "O you who have believed, avoid much [negative]

assumption" Indeed, some assumption is sin"

5-Not spy or backb ite each other

Surat A l-Hujurat [verse 12] "And do not spy or backbite each other. Would one of you

like to eat the flesh of his brother when dead? You would detest it And fear Allah; indeed,

Allah is Accepting of repentance and Merciful.

6-AVoid the use of words unclear, ironic, amb iguous and vague

Surah Al-Kahf [18:22] "...So do not argue about them except with an obvious

argunent..."

7-Self-control

Surah Ali 'Imran [3:200] "O you who have believed, persevere and endure and remain

stationed and fear Allah that you may be successful."

8- Empathy and care

Surah 3. Al-i'Imran, "Ayah 103: And hold firmly to the rope of Allah all together and do

Fig 2: Collaborative learning and social negotiation ethics

\subsection{Experience-based DSRM}

Design Science Research Methodology, adapted from [13] is used for iterative design-evaluation of Web 2.0-based CL and user testing. The social constructivist theory as a knowledge base and scientific foundation supports all design process in this study that was explained in the theoretical model. The 2 iterative cycles of design-valuation help us get feedback for refining the design process from the application domain. This help learners and participants actively engage in debate and social negotiation that supports the development of collaborative learning and social negotiation competencies better than theory-based methodology.

\section{Validity of the Theoretical model, Action plan and ethical system}

This study planned for internal design-evaluation in a natural situation with a group of students and experts based on [14] study. This evaluation is conducted in two parts: ex ante and ex post evaluations. The Ex ante evaluation is conducted prior to the artifact's construction (theoretical model, action plan and ethical system), then instantiation validity in 2 cycles of design-evaluation.

\subsection{Expert review}

3.1.1Revision of the theoretical model, Constructs, Action Plan and Design Guidelines

Experts who work in educational training, and ICT reviewed the developing theoretical model and action plan. A lecturer from the Universiti Teknologi MARA (UITM), who is the instructional designer evaluated "Theoretical model" and design strategy and confirmed their validity and effectiveness. She reviewed the developing action and implementation plan which describes practical activities to achieve learning goals and confirmed the detailed explanation which are mentioned in Table 1.

\subsubsection{Evaluation of Ethical system}

The researcher participated in a Quran class organised by the IIUM branch of the World Assembly of Muslim Youth (WAMY) and the Course Coordinator was the head of this centre. He reviewed and confirmed this study's developed Web 2.0-based collaborative learning's ethics which are based on verses of the Quran The discussions in the Quran class were conducted on the methods of debate in the IIUM English debate club. The findings of expert review, literature review and participant observation show that debate and negotiation based on verses of the Quran could lead to collaboration and empathy. Competitive structures, however, reduce generosity, empathy, sensitivity to others' needs, accuracy of communication and trust. Additionally, one expert in the Quran and Hadith from IIUM's Kulliyyah of Islamic Revealed Knowledge and Human Sciences (KIRKHS) read all the verses, discussed with the researcher and explained them. He confirmed the ethical system based on verses of the Quran and emphasised on the need to use the ethical system in Facebook-based collaborative learning and social negotiation based on his experiences in negotiation on Facebook.

\subsection{Peer review}

The researcher selected a $\mathrm{PhD}$ student who has good experience using Facebook for group discussions and sharing knowledge with others. She used this study's developing, prototype then reviewed and participates in this study's interview. She mentioned the artifact's ability to enhance learner's motivation, critical thinking skill, group discussion, teamwork with empathy, sharing information, engagement and collaborative learning. The interviewee indicated that discussion and negotiation aspect in developing artifact has led to a deeper understanding of subjects and help learners to be 
more open-minded. The findings from peer-review show that the artifact (Facebook features) can provide multiple modes of learning and support the condition of instruction. She emphasized the needs for training students and learners on how to use the artifact and manage the privacy setting on Facebook.

\subsection{Instantiation Validity in 2 Cycles Of Design- Evaluation And Communication}

\subsubsection{Loop 1: Face-Face Participant observation}

Face- Face participant observation in the 1st IIUM Debate Series at Moot Court in 2015 allowed the researcher to learn about the issues related to collaborative learning and social negotiation in IIUM. The findings from participant observation show the English debate club's potential for CL and social negotiation, however, there is an urgent need for innovation in the debate process. The participation of more than 200 students in the debate championship show this club could motivate students. However the 2 students and 1 trainer in interviews with this study asserted that their main goal in debating is the practice of speaking English and conducting English debates. The other student who was engaged in debate in response to the researcher's question about the result of debate $(63 \%$ voted against the motion: "This house believes that freedom of speech should not extend to insult of religion") explained that it is possible sometimes our talking on the debate is not our real belief. Undoubtedly, this style of debate could be as a challenge to develop critical thinking. In addition, according to the format of the debate (British Parliamentary) the resolution is usually not established until 10 minutes before the debate round begins, and this type of debate requires no evidence. Since it would be unreasonable to expect this type of debate could contribute to the IWON goals that emphasis on research and critical thinking. Therefore, all findings show in spite of success in motivating students and developing their skills for speaking English, there is an urgent need for innovations. Findings from expertreview, peer- review and literature review show this study's developing artifact potential to promote innovation in debate style and to encourage more research-oriented and evidence-based negotiation. This innovation will develop critical thinking and awareness of learners. [17] and [8] studies show integration of ICT to CL and social negotiation could improve these methods of instruction. In addition, findings from online participant observation confirmed the validity and effectiveness of developed artifact in promoting CL goals.

\subsubsection{Loop 2Online Participant Observation}

In this phase of design-evaluation, considering all findings in the first cycle, this study planned to instantiate and use developing artifact for debate and negotiation. The experiences and evaluation of artifact could help its improvement. In addition, this experience could be as a real example of integrating ICT to debate and social negotiation. Based on the researcher experiences and findings from participant observation in the first cycle, in the second loop, championship. This study recommended writing articles with team research and the participation of all groups, to improve CL rather than competition.

This real example of evidence-based and research oriented debating confirmed the effectiveness of this study developed framework. With regards to all findings and considering the active Facebook page of the English debate club, this study's developing web 2.0 artifact with Islamic ethical system could be as a good model for improving the problematic situation in this center. Social negotiation is required for all face-to-face collaborations and exists in computer-mediated collaboration in many forms. The constructivist theory emphasis on self-control and collaboration with empathy rather than competition. Learners are required to articulate and defend their ideas [20-22] based on reliable resource. This definition and rules in social constructivist theory for collaborative learning are compatible with the verse (3:200) of the Quran. the developing artifact was used in the real examples and the instantiation grounded by [18], [11] and [19] researches. This study created a personal account on Facebook and became friends with students, lecturers, experts and all people who want to join them. The researcher's participation and engagement on Facebook can be useful for management of discussion process and determining whether or not the $\mathrm{CL}$ is being delivered and operated as planned. These observations and practical engagement are also useful if the researcher encounters a problem. Findings show an urgent need for using the ethical system in negotiation and debate process. Regarding all feedbacks the researcher came back to design step and refined developing artifact with adding ethical system (Fig2) and rules of negotiation on Facebook's wall that all participants must obey these rules.

The researcher experiences in using artifact and recommendation of experts show, debate and negotiation based on developing, ethical system could lead to collaboration and empathy, while competitive structures reduce empathy to others' needs, accuracy of communication, and trust. In addition, the evidence-based negotiation and sharing information with reliable references promote the skills for seeking knowledge and critical thinking that are the main goals of IWON

\section{Communication}

Hevner and Chatterjee (2010) recommend additional research to generalize the research results to broader domains [14]. Thus, in the sixth step of the DSRM, the research team planned to communicate with a relevant audience and investigate their perception about the usefulness of the artifact and their intention of using it. The researcher conducted an interview and introduced this study's artifact to the previous head of the Academic Centre for Education, Culture and Research (ACECR) (Persian: جهاد دانشخاهى), an Iranian public non-governmental higher education institution who has developed the debate and negotiation framework based on the Islamic world view for university students. The researcher participated in a university debating championship in IRAN and found their evidence-based debate style with research, promote more critical thinking and knowledge- seeking skills. In addition, the teamwork and collaboration in their debate team promote more $\mathrm{CL}$ and social negotiation competency. However, there is an urgent need to develop more collaboration between all participants in debating championship. This study recommended writing articles with team research and the participation of all groups, to improve $\mathrm{CL}$ rather than competition.

This real example of evidence-based and research oriented debating confirmed the effectiveness of this study developed framework With regards to all findings and considering the active Facebook page of the English debate club, this study's developing web 2.0 artifact with Islamic ethical system could be as a good model for improving the problematic situation in this center. Social negotiation competency. However, there is an urgent need to develop more collaboration between all participants in debating

The Overall results of three cycles of design-evaluation and communication step of DSRM are shown in Table 2.The 
Table 2:Overall results of three cycles and communication step of DSRM

\begin{tabular}{|c|c|c|c|}
\hline Evaluation phase & $\begin{array}{c}\text { Method of eval- } \\
\text { uation }\end{array}$ & Design-evaluation Process & Overall Results \\
\hline $\begin{array}{l}\text { Evaluation of theoretical } \\
\text { model, Constructs, Action } \\
\text { Plan and Design Guide- } \\
\text { lines }\end{array}$ & Expert review & $\begin{array}{l}\text { Categorization of all goals, determination con- } \\
\text { structs, practical activities to achieve goals, } \\
\text { design strategies with using FB features, ethical } \\
\text { system according verses of Quran }\end{array}$ & $\begin{array}{l}>\quad \begin{array}{l}\text { Confirmation the Quality and effectiveness } \\
\text { of artifact and emphasis on its debate and } \\
\text { social negotiation potential. }\end{array} \\
>\quad \text { emphasis on the need to use the ethical } \\
\text { system in Facebook-based debate and social } \\
\text { negotiation }\end{array}$ \\
\hline $\begin{array}{l}\text { Practical Evaluation in } \\
\text { using artifact } \\
\text { (utility, qualityand effec- } \\
\text { tiveness of artifact ) }\end{array}$ & Peer Review & Using artifact ,review artifact, interview & $\begin{array}{l}\text { Artifact potential for acquisition of debate } \\
\text { and social negotiation competencies } \\
\text { Confirmation the utility, Quality and effec- } \\
\text { tiveness of artifact and emphasis on its po- } \\
\text { tential for developing critical thinking and } \\
\text { awareness } \\
>\text { An emphasis on more training and practice, } \\
\text { using ethical system and setting privacy }\end{array}$ \\
\hline Instantiation (Loop 1) & $\begin{array}{l}\text { Face-Face Partic- } \\
\text { ipant observation } \\
\text { and interview }\end{array}$ & $\begin{array}{l}\text { Participation in IIUM debate championship, } \\
\text { interviews with trainers and students }\end{array}$ & $\begin{array}{l}>\text { IWON has successes to motivate students, } \\
\text { teach speaking English and conducting de- } \\
\text { bates } \\
\text { There is an urgent need to innovate the } \\
\text { debate process } \\
\text { The style of debate has not potential to } \\
\text { develop IWON goals: critical thinking, re- } \\
\text { search skills and awareness }\end{array}$ \\
\hline Instantiation (Loop 2) & $\begin{array}{l}\text { Online- Partici- } \\
\text { pant observation }\end{array}$ & $\begin{array}{l}>\quad \text { Instantiation a real example of integrating } \\
\text { ICT to debate and social negotiation } \\
\text { Creation FB account and adding people } \\
\text { The researcher's participation and engage- } \\
\text { ment in CL, debate and negotiation } \\
\text { The researcher came back to design step } \\
\text { and refined developing artifact with adding } \\
\text { ethical system and rules of negotiation on } \\
\text { Facebook's wall that all participants must } \\
\text { obey these rules. }\end{array}$ & $\begin{array}{l}\text { An urgent need for using the ethical system } \\
\text { in negotiation and debate process } \\
\text { Debate and negotiation based on develop- } \\
\text { ing, ethical system could lead to CL, empa- } \\
\text { thy, while competitive structures reduce } \\
\text { empathy to others' needs, accuracy of com- } \\
\text { munication, and trust. } \\
\text { The evidence-based negotiation and sharing } \\
\text { information with reliable references promote } \\
\text { the skills for seeking knowledge and critical } \\
\text { thinking that are the main goals of IWON. }\end{array}$ \\
\hline Communication & $\begin{array}{l}\text { Face-Face Partic- } \\
\text { ipant observation } \\
\text { and interview }\end{array}$ & $\begin{array}{l}>\quad \text { Generalizing the research results } \\
>\quad \text { Diffusing artifact to application domain } \\
\text { Finding a real example of using the artifact } \\
\text { in the university debating championships } \\
>\quad \text { Interview with the Iranian designer of } \\
\text { Islamic debate style } \\
>\quad \text { Participation in an Iranian debating cham- } \\
\text { pionship }\end{array}$ & $\begin{array}{l}\text { The Islamic evidence-based debate style } \\
\text { with research, promote more critical think- } \\
\text { ing and knowledge- seeking skills } \\
\text { The teamwork and collaboration in debate } \\
\text { team promote more CL and social negotia- } \\
\text { tion competency. } \\
\text { This real example of evidence-based and } \\
\text { research oriented debating confirmed the ef- } \\
\text { fectiveness of this study developed frame- } \\
\text { work. } \\
\text { This study recommended writing articles } \\
\text { with participation of all groups to improve } \\
\text { CL rather than competition }\end{array}$ \\
\hline
\end{tabular}

\section{Conclusions}

The research was iterative cycles of design-evaluation that encompassed a preliminary investigation in the theoretical model of debate and social negotiation and an active approach in using innovative Web 2.0-based CL for motivating learners to engage in debate and social negotiation to achieve social constructivist theory goals. The artifact includes methods of CL, social negotiation and action plan for defining theory into practice. This action plan supports the development of critical thinking, awareness and CL competencies. Facebook as a web 2.0 tool was considered as a delivery tool in this study that promote the opportunity to open learning and online negotiation. The developed Islamic ethical system's validity was confirmed with expert review and experience-based methodology. This study will contribute to IDEA and WUDC that aim to promote skills for knowledge seeking and critical thinking in a safe and structured platform. 


\section{References}

[1] Dillenbourg, Pierre. (1999). "What do you mean by collaborative learning." Collaborative-learning: Cognitive and Computational Approaches 1 1-15.

[2] Vygotsky, L. S. (1978). The interaction between learning and development. In Mind in Society Cambridge MA: Harvard University Press.

[3] Sidek, B. (2005). The dynamics of Study Circles: Some reflections on ABIM's collaborative learning systems. Malaysia: Darul Hikmah.

[4] Ataie.F, (2013). Facebook`s potential for Collaborative Learning: An Emerging Educational trend in promoting lifelong learning in IIUM, International Journal of Information Technology Computer Science (IJITCS), 7(1)

[5] Ataie.F, Shah. A, Mior Nazir, M.N. (2014). "Innovative web 2.0 based collaborative learning and Study Circle model," Information and Communication Technology for The Muslim World (ICT4M), 2014 The 5th International Ataie Conference on 17-18 Nov, 2014

[6] Driscoll, M.P. (2005). Psychology of Learning for Instruction (pp.384-407); Ch.11-Constructivism.

possibilidade para a integração curricular das TIC na escolaridade básica.

[7] Llorens. F; Capdeferro. N (2011). "Facebook's Potential for Collaborative e-Learning" [online article]. Revistade Universidady Sociedad del Conocimiento (RUSC). 8(2), 197-210.

[8] Cruz, S. C. \& carvalho, A. A. (2006). Modelo ITIC: uma possibilidade para a integração curricular das TIC na escolaridade básica

[9] Du, H.-J., Shin, D.-H. and Lee, K.-H. (2008). A sophisticated approach to semantic web services discovery. Journal of Computer Information Systems, 48(3), 44-60.

[10] Julia, J. (2012). Potentials of Facebook as a Pedagogical Tool for College Lecturers Julia. Journal Communication Spectrum, 1(2).

[11] McLaren, T. S., Head, M. M., Yuan, Y. and Chan, Y. E. (2011). A multilevel model for measuring fit between a firm's competitive strategies and information systems capabilities. MIS Quarterly, 35(4), 909-930

[12] Hashim, C. N., \& Hassan, S. S. S. (2013). A Comparative Study on Cyber Ethics, Religious Awareness, and Satisfaction in Using Facebook for Social Networking. Academic Journal of Interdisciplinary Studies, 2(3), 419.

[13] Hevner, R. F., Daza, R. A. M., Englund, C., Kohtz, J., \& Fink, A. (2004). Postnatal shifts of interneuron position in the neocortex of normal and reeler mice: evidence for inward radial migration. Neuroscience, 124(3), 605-618.

[14] Hevner, A., \& Chatterjee, S. (2010). Design science research in information systems (pp. 9-22). Springer US.

[15] Venable, J., Pries-Heje, J., \& Baskerville, R. (2012, May). A comprehensive framework for evaluation in design science research. In International Conference on Design Science Research in Information Systems (pp. 423-438). Springer Berlin Heidelberg.

[16] IDEA, 2018. International Debate Education Association Education Retrieved from https://idebate.org/about-idea-nw

[17] Khan, B. H. (2005). Managing e-learning: Design, Delivery, Implementation and Evaluation. Hershey, PA: Information Science Publishing.

[18] Du, H.-J., Shin, D.-H. and Lee, K.-H. (2008). A sophisticated approach to semantic web services discovery. Journal of Computer Information Systems, 48(3), 44-60.

[19] Pries-Heje, J. and Baskerville, R. (2008). The design theory nexus. MIS Quarterly, 32 (4), 731-755.

[20] Smith, B. L. and MacGregor, J. T. (1992). "What is collaborative learning?" In Goodsell, A. S., Maher, M. R., and Tinto, V. (Eds.), Collaborative Learning: A Sourcebook for Higher Education. National Center on Postsecondary Teaching, Learning, \& Assessment, Syracuse University,

[21] Ahmed, S. F. (2007, December). A new approach in Industrial automation application" Embedded system design for Injection Molding Machine". In Multitopic Conference, 2007. INMIC 2007. IEEE International (pp. 1-5). IEEE

[22] Ahmed, S. F., Kushsairy, K., Bakar, M. I. A., Hazry, D., \& Joyo, M. K. (2015, April). Attitude stabilization of Quad-rotor (UAV) system using Fuzzy PID controller (an experimental test). In Computing Technology and Information Management (ICCTIM), 2015 Second International Conference on (pp. 99-104). IEEE. 